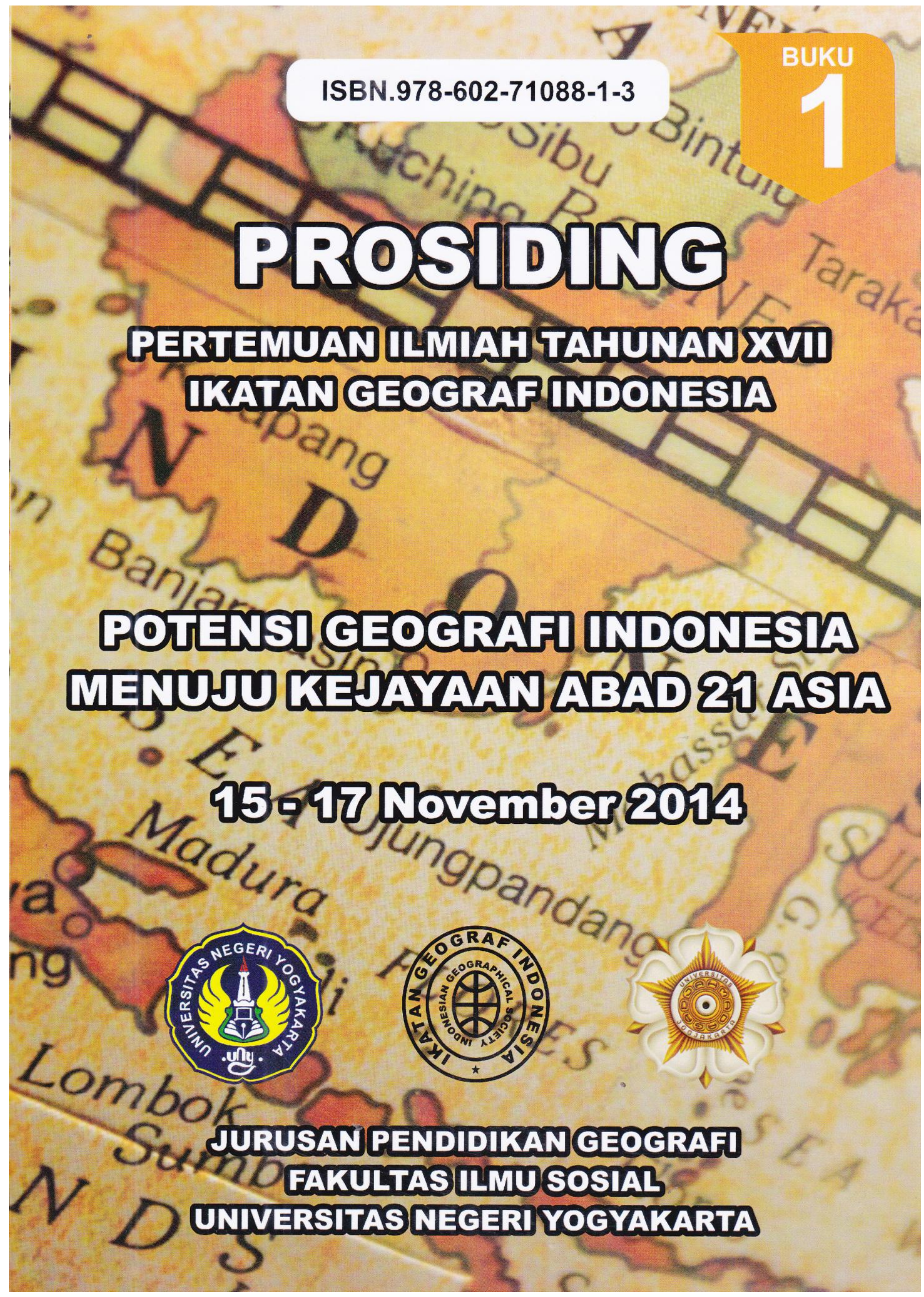


PROSIDING PERTEMUAN ILMIAH TAHUNAN - 2014

IKATAN GEOGRAF INDONESIA

"POTENSI GEOGRAFI INDONESIA MENUJU KEJAYAAN ABAD 21 ASIA"

ISBN. 978-602-71088-1-3

\section{Penyunting}

Dr. Hastuti

Suhadi Purwantara, M.Si.

Dyah Respati Suryo Sumunar, M.Si.

\section{Diterbitkan Oleh}

Jurusan Pendidikan Geografi

Fakultas IImu Sosial - Universitas Negeri Yogyakarta

\section{Alamat Redaksi}

Jurusan Pendidikan Geografi

Fakultas IImu Sosial - Universitas Negeri Yogyakarta

Karangmalang, Yogyakarta. 55281

Telepon. 0274 - 586168 Ext. 386

Email: unygeografi@yahoo.co.id 


\title{
TREND PERKEMBANGAN PENDUDUK DAN IMPLIKASINYA TERHADAP KEBUTUHAN RTH (RUANG TERBUKA HIJAU) DI D.I. YOGYAKARTA
}

\author{
Oleh \\ Mohammad Isnaini Sadali \\ Program Studi Pembangunan Wilayah Fakultas Geografi Universitas Gadjah Mada \\ JI. Kaliuran - Bulaksumur, Kab. Sleman, D.I. Yogyakarta \\ m.isnaini.s@ugm.ac.id.
}

\begin{abstract}
ABSTRAK
Peningkatan dan pertambahan penduduk alamiah maupun non alamiah akan menjadi pemicu perubahan fungsi kota. Pertambahan penduduk akan diikuti oleh meningkatnya kebutuhan lahan permukiman yang mendorong terjadinya alih fungsi lahan. Tekanan penduduk terhadap lahan akan meningkat seiring dengan pertambahan jumlah penduduk, dengan bertambahnya jumlah penduduk berarti bertambah pula luas lahan yang digunakan untuk permukiman dan sarana prasarana pendukung lainnya. Akibatnya lahan pertanian, lahan lindung maupun lahan untuk RTH akan semakin menyempit. Salah satu upaya yang dapat dilakukan untuk menjaga pemanfaatan dan pengendalian alih fungsi lahan yang tidak berkelanjutan adalah dengan mempertahankan ruang terbuka hijau (RTH) sesuai UU No. 26 Tahun 2007 yang mensyaratkan penyediaan RTH dengan luas minimal sebesar $30 \%$ dari luas wilayah. Tujuan dari penelitian ini adalah: (1) Mengetahui tren perkembangan penduduk di D.I. Yogyakarta; dan (2) Menganalisis implikasi perkembangan penduduk terhadap kebijakan terkait RTH dan kebutuhan RTH di DIY. Pendekatan yang digunakan dalam penelitian ini adalah pendekatan rasionalistik. Penelitian ini menggunakan metode penelitian kuantitatif dengan data sekunder sebagai data utama dan dianalisis secara deskriptif. Hasil dari penelitian ini adalah tren dan kecenderungan perkembangan penduduk yang mengalami peningkatan dari tiap tahunnya (2004-2022), fluktuasi pertambahan penduduk dan pegurangan penduduk yang cukup signifikan terjadi pada tahun 2007-2010. Kebutuhan RTH per kapita di D.I. Yogyakartaberbanding lurus dengan perkembangan penduduk. RTH yang dibutuhkan di D.I. Yogyakarta berupa Taman Kecamatan sejumlah 30 unit, sedangkan kebutuhan RTH berupa taman kota dan hutan kota berjumlah 7 unit dengan luas yang bervariasi pada masing-masing kabupaten sesuai dengan jumlah penduduk yang dilayani. Melalui perhitungan penyediaan RTH di D.I. Yogyakarta diharapkan dapat direncanakan dan dipertahankan untukkesesuaian kebutuhan RTH bagi penduduk yang dilayani, daya dukung lingkungan dan antisipasi alih fungsi lahan.
\end{abstract}

Kata kunci: tren, perkembangan, penduduk, RTH, wilayah

\section{PENDAHULUAN}

Kebutuhan penduduk yang paling mendasar selain pangan dan sandang adalah tempat tinggal yang sering disebut dengan lahan permukiman. Kebutuhan lahan permukiman akan terus meningkat seiring dengan perkembangan penduduk pada 
suatu wilayah. Perkembangan penduduk dapat dilihat melalui pertambahan penduduk yang pada dasarnya dipengaruhi oleh beberapa faktor demografi, antara lain: kematian (mortalitas), kelahiran (natalitas), dan migrasi (mobilitas). Kelahiran dan kematian merupakan faktor alami yang terjadi dalam pertambahan penduduk, sedangkan perpindahan penduduk atau migrasi merupakan faktor non alami. Kecenderungan perkembangan penduduk yang terjadi di Indonesia secara umum dan di D.I. Yogyakarta saat ini adalah populasi penduduk akan cenderung mengelompok dan banyak pada wilayah perkotaan atau pusat kegiatan tertentu. Menurut Yunus (2002) daerah pusat kegiatan merupakan pusat kehidupan sosial, ekonomi, budaya, dan politik dalam suatu kota sehingga pada kawasan ini terdapat bangunan utama untuk kegiatan sosial ekonomi. Pusat kegiatan pada suatu wilayah mampu memberikan daya tarik bagi beberapa penduduk yang memang memiliki kepentingan dan motif tertentu dengan harapan dapat diwujudkan pada daerah tujuan.

Pusat kegiatan wilayah tentu didukung oleh rute transportasi dari segala penjuru yang memusat pada wilayah ini, sehingga menjadikan pusat kegiatan wilayah memiliki derajat aksesibilitas tertinggi. Hal ini justru mendorong dan mempermudah penduduk untuk melakukan mobilitas serta migrasi masuk menuju wilayah tersebut. D.I. Yogyakarta yang merupakan salah satu provinsi di Indonesia sudah terkenal dengan beberapa image yang melekat mampu memberikan daya tarik untuk dikunjungi hingga dijadikan tempat tinggal. D.I. Yogyakarta terkenal dengan penduduknya yang ramah, budayanya, tujuan wisata, pendidikan (pelajar), dan masih banyak lagi. Daya tarik tersebut mampu mempengaruhi penduduk yang memiliki tempat tinggal jauh cenderung akan menetap pada wilayah tertentu yang dekat dengan daerah tujuan, sedangkan penduduk dengan jarak yang dekat dengan daerah tujuan akan melakukan mobilitas. Pertambahan penduduk yang diikuti oleh meningkatnya kebutuhan lahan permukiman di D.I. Yogyakarta tidak dapat dielakkan lagi. Hal ini mendorong terjadinya alih fungsi lahan, termasuk yang pada awalnya merupakan ruang terbuka hijau menjadi lahan terbangun. Seiring dengan perkembangan jumlah penduduk diD.I. Yogyakarta akan berimbas pada perubahan lanskap dengan bergesernya pemanfaatan ruang di dalamnya.

Perubahan status keistimewaan Yogyakarta yang menyangkut prioritas pembangunan dan penataan ruang akan berpengaruh pada aspek kependudukan, termasuk di dalamnya manusia dan kebudayaannya yang menjadi faktor 
ketidakseimbangan penataan ruang.Peningkatan dan pertambahan penduduk alamiah maupun non alamiah (migrasi) akan menjadi pemicu perubahan fungsi kota. Sistem yang bekerja dari regulasi sektoral dalam batasan lingkup administrasi juga memberikan andil yang besar terhadap terjadinya migrasi (McGee, 1977). Perkembangan penduduk yang sedemikian pesat menuntut upaya perencanaan, pemanfaatan dan pengendalian lahan secara sinergis, berkesinambungan dan pro lingkungan.Tekanan penduduk terhadap lahan akan meningkat seiring dengan pertambahan jumlah penduduk, dengan bertambahnya jumlah penduduk berarti bertambah pula luas lahan yang digunakan untuk permukiman dan sarana prasarana pendukung lainnya yang memakan lahan juga. Akibatnya lahan pertanian dan lahan lindung akan semakin menyempit, akhirnya daya dukung lahan pertanian akan melampaui batas kemampuan lahan untuk kehidupan layak bagi penduduk (Soemarwoto, 1998).

Salah satu upaya yang dapat dilaksanakan dalam menjaga pemanfaatan dan pengendalian alih fungsi lahan yang tidak berkelanjutan adalah dengan mempertahankan ruang terbuka hijau (RTH). Amanat dari UU No. 26 Tahun 2007 tentang Penataan Ruang, penyediaan RTH disyaratkan dengan luas RTH minimal sebesar $30 \%$ dari luas wilayah kawasan perkotaan yang dibagi menjadi RTH Publik minimal 20\% dan RTH Privat minimal 10\%. Pada kenyataannya, terjadi penurunan kuantitas Ruang Terbuka Hijau yang sangat signifikan di kawasan perkotaan yang menyebabkan menurunnya kualitas ruang terbuka publik perkotaan. Penataan ruang wilayah berkelanjutan merupakan salah satu jalan keluar yang dipandang efektif untuk mengatasi masalah alih fungsi lahan dan sebagai kunci pembangunan. Disahkannya Peraturan Daerah No. 2 Tahun 2010 mengenai RencanaTata Ruang Wilayah (RTRW) D.I. Yogyakartamerupakan alat dalam mengkoordinasikan pembangunan secara berkelanjutan. Selaras dengan amanat Undang-Undang Penataan Ruang pasal 3, perlu diwujudkan suatu bentuk pengembangan kawasan perkotaan yang mengharmonisasikan lingkungan alamiah dan lingkungan buatan. Upaya yang dapat dilakukan untuk membangkitkan kepedulian masyarakat dan mewujudkan keberlangsungan tata kehidupan lingkungan perkotaan dan perdesaan yang berkesinambungan antara lain dapat dilakukan dalam bentuk perwujudan Ruang Terbuka Hijau. 


\section{METODE}

Pendekatan yang digunakan dalam penelitian ini adalah pendekatan rasionalistik. Pendekatan rasionalistik merupakan cara berfikir dengan mengedepankan rasio dan fakta empiris. Pendekatan rasionalistik merupakan pandangan yang berkiblat pada pemikiran peneliti sebagai landasan kebenaran, sedangkan obyek/kebendaan bersifat tidak pasti, berubah-ubah, relatif dan kabur (Sadyohutomo, 2009). Penelitian ini menggunakan metode penelitian kuantitatif dengan data sekunder sebagai data utama dan dianalisis secara deskriptif.

Secara administratif daerah yang dipilih untuk penelitian ini sesuai dengan judul yaitu di Daerah Istimewa Yogyakarta yang terdiri dari 4 kabupaten (Sleman, Gunungkidul, Bantul, Kulon Progo) dan 1 kota (Yogyakarta).

Data pokok yang dikumpulkan: (1) Data series jumlah penduduk di D.I. Yogyakarta 10 tahun terakhir (tahun 2004, 2007, 2010, 2013); (2) Dokumen RTRW atau Perda RTRW D.I. Yogyakarta Tahun 2010; (3) Peta dasar Daerah Istimewa Yogyakarta.

Data jumlah penduduk dari tahun 2004-2013 diolah dalam bentuk tabel dan grafik yang berupa tren perkembangan jumlah penduduk di Daerah Istimewa Yogyakarta. Hasil pengolahan data akan menunjukkan kecenderungan penurunan atau pertumbuhan penduduk dari tahun 2004-2013 sehingga membentuk suatu pola yang dapat dianalisis sebagai tren perkembangan penduduk.

Penyediaan RTH berdasarkan luas wilayah mengacu pada Peraturan Menteri PU No. 05/PRT/M/2008, sebagai berikut:

- $\quad$ RTH di perkotaan terdiri dari RTH privat dan RTH publik.

- Proporsi RTH pada wilayah perkotaan adalah sebesar minimal 30\% yang terdiri dari $20 \%$ RTH publik dan $10 \%$ RTH privat.

- Apabila luas RTH baik publik maupun privat di kota yang bersangkutan telah memiliki total luas lebih besar dari peraturan dan perundangan yang berlaku, maka proporsi tersebut harus tetap dipertahankan keberadaannya.

Mengacu pada Peraturan Menteri PU No. 05/PRT/M/2008 tentang penyediaan dan pemanfaatan ruang terbuka hijau, maka penentuan kebutuhan luas RTH berdasarkan jumlah penduduk dilakukan dengan mengalikan antara jumlah penduduk yang dilayani dengan standar luas RTH per kapita sesuai peraturan yang berlaku. Berikut adalah tabel penentuan luas minimal penyediaan RTH berdasarkan jumlah penduduk menurut tipe dan lokasi yang disarankan. 
Tabel 1. Penyediaan RTH Berdasarkan Jumlah Penduduk

\begin{tabular}{|c|c|c|c|c|c|}
\hline No & $\begin{array}{c}\text { Unit } \\
\text { Lingkungan }\end{array}$ & Tipe RTH & $\begin{array}{c}\text { Luas } \\
\text { minimal/ } \\
\text { unit }\left(\mathrm{m}^{2}\right)\end{array}$ & $\begin{array}{c}\text { Luas } \\
\text { minimal/ } \\
\text { kapita } \\
\left(\mathrm{m}^{2}\right)\end{array}$ & Lokasi \\
\hline 1 & 250 jiwa & Taman RT & 250 & 1 & di tengah lingkungan RT \\
\hline 2 & 2500 jiwa & Taman RW & 1.250 & 0,5 & di pusat kegiatan RW \\
\hline 3 & 30000 jiwa & $\begin{array}{l}\text { Taman } \\
\text { Kelurahan }\end{array}$ & 9.000 & 0,3 & $\begin{array}{l}\text { dikelompokan dengan } \\
\text { sekolah/ pusat kelurahan }\end{array}$ \\
\hline \multirow[t]{2}{*}{4} & $\begin{array}{l}120000 \\
\text { jiwa }\end{array}$ & $\begin{array}{l}\text { Taman } \\
\text { Kecamatan }\end{array}$ & 24.000 & 0,2 & $\begin{array}{l}\text { dikelompokan dengan } \\
\text { sekolah/ pusat kecamatan }\end{array}$ \\
\hline & & Pemakaman & disesuaikan & 1,2 & tersebar \\
\hline \multirow[t]{3}{*}{5} & 480000 & Taman kota & 144.000 & 0,3 & di pusat wilayah/ kota \\
\hline & jiwa & Hutan kota & disesuaikan & 4 & di dalam/ kawasan pinggiran \\
\hline & & $\begin{array}{l}\text { untuk fungsi- } \\
\text { fungsi tertentu }\end{array}$ & disesuaikan & 12,5 & $\begin{array}{l}\text { disesuaikan dengan } \\
\text { kebutuhan }\end{array}$ \\
\hline
\end{tabular}

Sumber: Peraturan Menteri PU No. 05/PRT/M/2008

\section{HASIL DAN PEMBAHASAN}

Daerah Istimewa Yogyakarta setingkat dengan provinsi di Negara Republik Indonesia dengan luas wilayah dari sebesar $3.185,80 \mathrm{~km}^{2}$. Daerah Istimewa Yogyakarta terdiri atas empat kabupaten (Kabupaten Sleman, Kabupaten Bantul, Kabupaten Gunungkidul dan Kabupaten Kulonprogo) serta satu kota yaitu Kota Yogyakarta.Daerah Istimewa Yogyakarta terletak pada $7^{\circ} 15$ - $8^{\circ} 15$ Lintang Selatan dan garis $110^{\circ} 5-110^{\circ} 4$ Bujur Timur, sebelah utara dibatasi oleh Kabupaten Magelang dan Kabupaten Klaten, sebelah timur berbatasan dengan Kabupaten Klaten dan Kabupaten Wonogiri, sebelah selatan dibatasi oleh Samudera Hindia, dan sebelah barat berbatasan dengan Kabupaten Purworejo. Secara administratif Daerah Istimewa Yogyakarta meliputi 1 kota dan 4 kabupaten, 78 kecamatan, 45 kelurahan dan 393 desa. Jumlah kecamatan dan desa pada masing-masing kabupaten/kota di Daerah Istimewa Yogyakarta adalah:Kota Yogyakarta terdiri dari 14 kecamatan dan 45 kelurahan; Kabupaten Sleman terdiri dari 17 kecamatan dan 86 desa; Kabupaten Kulon Progo terdiri dari 12 kecamatan dan 88 desa; Kabupaten Gunungkidulterdiri dari 18 kecamatan dan 144 desa;sedangkan Kabupaten Bantulterdiridari 17 kecamatan dan 75 desa.

\section{Tren Perkembangan Penduduk di D.I. Yogyakarta}

Dinamika pertumbuhan penduduk yang terjadi di D.I. Yogyakarta dapat mendatangkan dampak positif dan negatif bagi perkembangan wilayah. Pertambahan 
jumlah penduduk akan diiringi dengan meningkatnya kebutuhan lahan untuk permukiman. Berkurangnya lahan yang difungsikan untuk penghijaun dalam suatu wilayah dapat membahayakan kehidupan masyarakat dan dapat merusak ekosistem alami yang terdapat di wilayah tersebut. Berdasarkan data jumlah penduduk D.I. Yogyakarta tahun 2004, 2007, 2010 dan 2012 yang divisualisasikan dalam Gambar 1 yang berupa diagram garis dapat diketahui bahwa pertumbuhan jumlah penduduk antara kelima kabupaten/kota berbeda satu sama lain.Jumlah penduduk terbesar di D.I. Yogyakarta dari tahun 2004-2012 berada di Kabupaten Sleman dengan pertambahan penduduk hingga $24 \%$, bahkan melebihi jumlah penduduk dari Kota Yogyakarta sebagai ibu kota provinsi.Perkembangan penduduk di Kabupaten Sleman lebih signifikan dibandingkan dengan kabupaten/kota yang lain terutama pada tahun 2007-2010.Kabupaten yangmemiliki jumlah penduduk cukup besar setelah Kabupaten Sleman adalah Kabupaten Bantul, dengan jumlah pertambahan penduduk dari 20042012 mencapai $16 \%$.

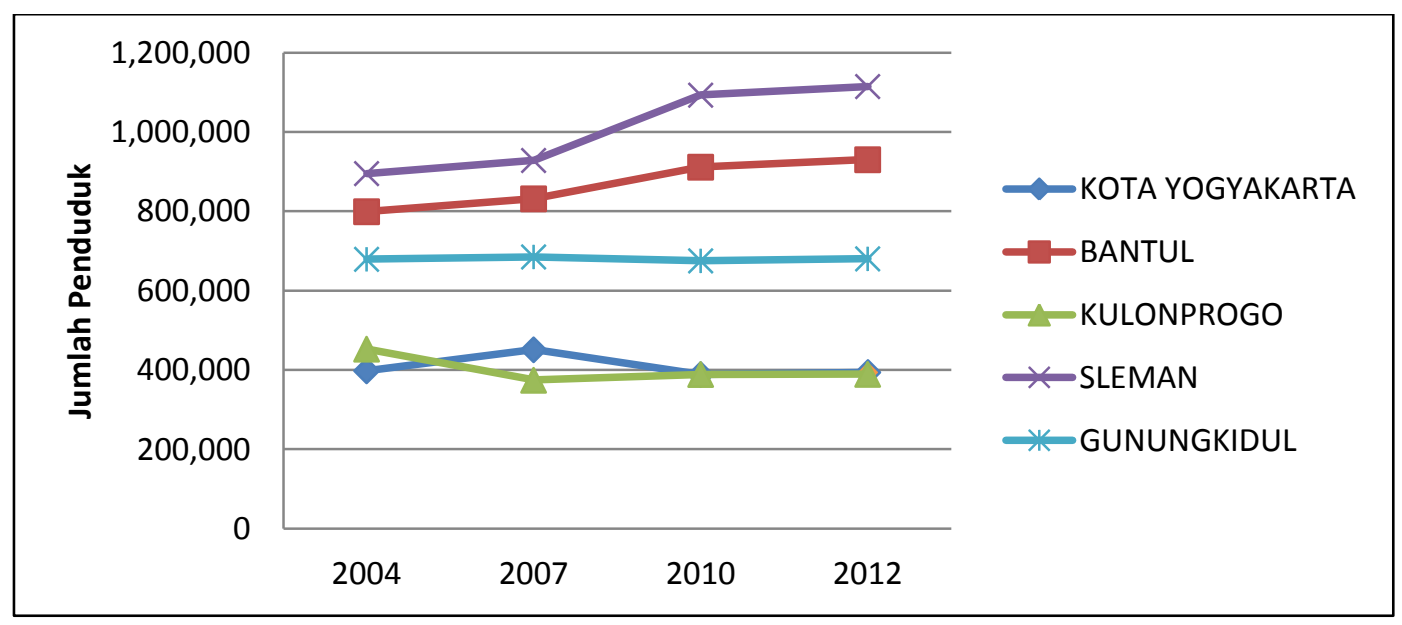

Gambar 1. Tren Perkembangan Penduduk D.I. Yogyakarta dari Tahun 2004-2012

Grafik di atas menunjukkan bahwa pertumbuhan penduduk di Kabupaten Gunungkidul lebih cenderung stabil, tidak terdapat kenaikan maupun penurunan yang signifikan di kabupaten ini. Berbeda dengan kedua wilayah lainnya yaitu Kabupaten Kulonprogo dan Kota Yogyakarta, kedua wilayah ini mengalami dinamika kenaikan dan penurunan jumlah penduduk. Kota Yogyakarta mengalami kenaikan yang cukup signifikan pada tahun 2007, sedangkan Kabupaten Kulonprogo mengalami penurunan jumlah penduduk pada tahun yang sama. Namun demikian pada tahun-tahun berikutnya pertumbuhan jumlah penduduk pada kedua wilayah ini cenderung stabil dengan kenaikan yang tidak terlalu signifikan. Jumlah penduduk D.I. Yogyakarta dari 
tahun 2004, 2007, 2010 dan 2012 diproyeksikan berdasarkan tren perkembangan penduduk hingga tahun 2022. Hasilnya adalah Kabupaten Sleman dan Kabupaten Bantul terus mengalami peningkatan jumlah penduduk dengan jumlah penduduk terbesar tetap berada di Kabupaten Sleman. Jumlah penduduk dan hasil proyeksi penduduk D.I. Yogyakarta dari tahun 2004-2022 dapat dilihat pada Tabel 2.

Tabel 2. Jumlah Penduduk D.I. Yogyakarta dari Tahun 2004-2022 Berdasarkan Kabupaten/Kota

\begin{tabular}{|c|c|c|c|c|c|c|c|c|c|}
\hline No & Kabupaten/Kota & 2004 & 2007 & 2010 & 2012 & 2013 & 2016 & 2019 & 2022 \\
\hline 1 & Kota Yogyakarta & 398.004 & 451.118 & 388.627 & 394.012 & 397.421 & 404.563 & 411.812 & 419.062 \\
\hline 2 & Kab. Bantul & 799.211 & 831.657 & 911.503 & 930.276 & 956.517 & 1.020 .558 & 1.084 .599 & 1.148 .640 \\
\hline 3 & Kab. Gunungkidul & 679.320 & 685.210 & 675.382 & 680.406 & 684.885 & 694.383 & 703.968 & 713.554 \\
\hline 4 & Kab. Kulon Progo & 452.812 & 374.335 & 388.869 & 389.213 & 389.503 & 390.223 & 390.943 & 391.663 \\
\hline 5 & Kab. Sleman & 895.327 & 928.471 & 1.093 .110 & 1.114 .833 & 1.156 .283 & 1.254 .036 & 1.351 .807 & 1.449 .580 \\
\hline
\end{tabular}

Berdasarkan hasil proyeksi jumlah penduduk, Kabupaten Sleman mengalami peningkatan yang signifikan pada tiap tahunnya sehingga pada tahun 2022 mencapai jumlah 1.449.580 jiwa. Hal yang tidak jauh berbeda juga terjadi pada Kabupaten Bantul yang mengalami peningkatan pada tiap tahunnya sehingga mencapai angka 1.148.640jiwa di tahun 2022.Berbeda dengan kedua kabupaten tersebut, Kabupaten Gunungkidul, Kabupaten Kulonprogo, dan Kota Yogyakarta hanya sedikit mengalami peningkatan jumlah penduduk, atau terlihat lebih konstan atau stabil. Jumlah penduduk Kabupaten Gunungkidul pada tahun 2022 mencapai angka 713.554 jiwa, jumlah penduduk Kabupaten Kulonprogo mencapai 391.663 jiwa, dan jumlah penduduk Kota Yogyakarta mencapai 419.062 jiwa.

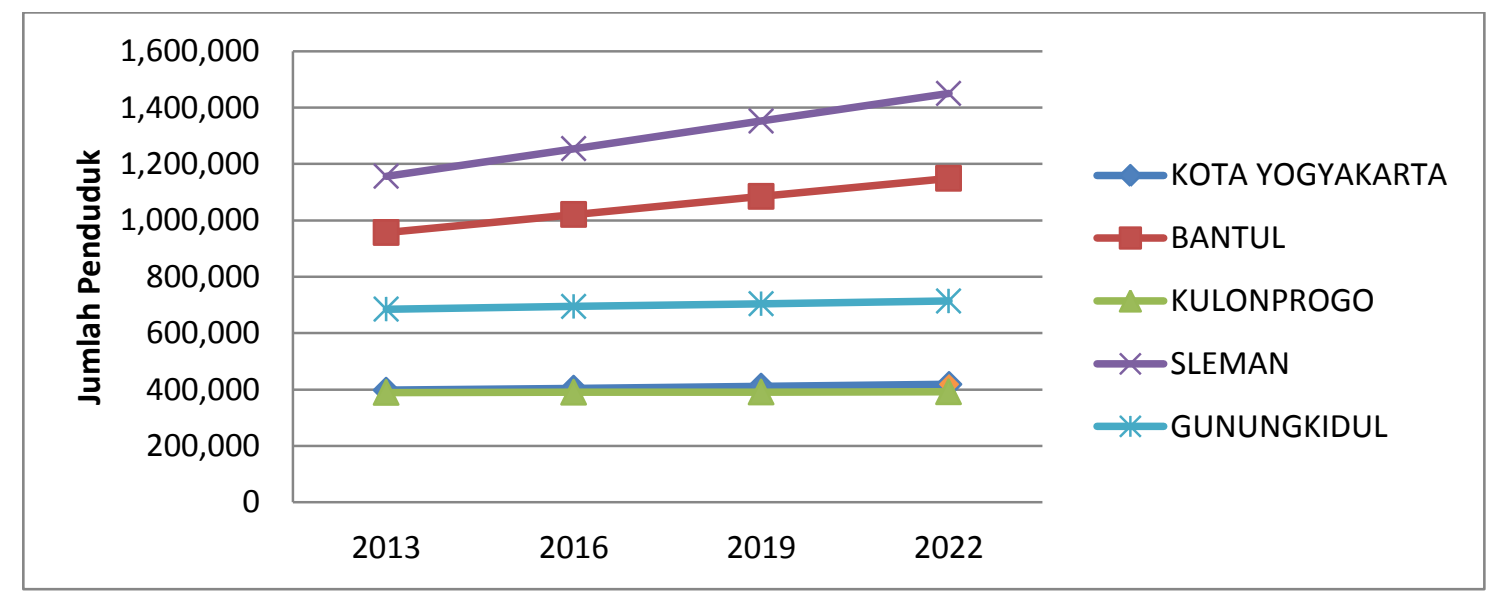

Gambar 2. Tren Perkembangan Penduduk D.I. Yogyakarta dari Tahun 2013-2022 


\section{Implikasi Perkembangan Penduduk terhadap Kebijakan dan Kebutuhan RTH di D.I. Yogyakarta}

Di dalam Rencana Tata Ruang Wilayah D.I. Yogyakarta Nomor 2 tahun 2010 menjelaskan bahwa banyaknya perubahan tata guna lahan menjadikan ruang terbuka hijau menjadi sasaran utama dalam perubahan tata guna lahan tersebut. Pemicu utama perubahan penggunaan lahan di Daerah Istimewa Yogyakarta adalah pertumbuhan penduduk yang cukup tinggi. Adapun beberapa permasalahan penggunaan lahan di D.I. Yogyakarta khususnya Ruang Terbuka Hijau diantaranya:

- Alih fungsi lahan pertanian subur di kawasan lahan basah untuk kepentingan non pertanian.

- Pemanfaatan lahan untuk permukiman-pertambangan di sekitar kawasan lindung.

- Adanya pengaruh kegiatan pembangunan yang berdampak pada sulitnya pengendalian konversi lahan.

Permasalahan tersebut membuktikan bahwa lahan untuk ruang terbuka hijau di D.I. Yogyakarta semakin berkurang, di sisi lain pertumbuhan penduduk semakin bertambah dan membutuhkan ruang yang semakin banyak.Berdasarkan pada prospek pembangunan dan pengembangan RTH di D.I. Yogyakarta, maka dapat dirumuskan Kebijakan Pembangunan dan Pengembangan RTH:

- Kebijakan Pengendalian RTH, meliputi: memperkuat mekanisme perijinan danmengembangkan mekanisme punishment dan reward.

- Kebijakan Pengelolaan dan Pemeliharaan RTH: memperkuat kelembagaan instansi pengelola RTH publik dan mendorong peran serta masyarakat, dan kerjasama swasta.

\section{Kebutuhan RTH Berdasarkan Luas Wilayah}

Menurut Undang-Undang Nomor 26 Tahun 2007 Tentang Penataan Ruang, Ruang Terbuka Hijau adalah area memanjang/jalur dan/atau mengelompok, yang penggunaannya lebih bersifat terbuka, tempat tumbuh tanaman, baik yang tumbuh secara alamiah maupun yang sengaja ditanam. Ruang terbuka hijau terdiri dari ruang terbuka hijau publik dan ruang terbuka hijau privat, dimana paling sedikit adalah $30 \%$ dari luas wilayah kota. Proporsi Ruang Terbuka Hijau Publik paling sedikit 20\% dan proporsi Ruang Terbuka Hijau Publik paling sedikit 10\% dari luas wilayah kota. Ruang terbuka hijau publik merupakan ruang terbuka hijau yang dimiliki dan dikelola oleh 
pemerintah daerah kota yang digunakan untuk kepentingan masyarakat secara umum.

Berdasarkan data D.I. Yogyakarta dalam angka yang dikeluarkan oleh BPS, luas wilayah keseluruhan D.I. Yogyakarta sebesar 3.185,8 km². Mengacu pada UndangUndang Nomor 26 Tahun 2007 tersebut, maka dapat dilakukan perhitungan terhadap kebutuhan Ruang Terbuka Hijau yang seharusnya disediakan dan dipenuhi oleh D.I. Yogyakarta sebesar 30\%, yaitu 955,47 $\mathrm{km}^{2}$. Luas Ruang Terbuka Hijau dirinci lagi berdasarkan fungsi penyediaannya yaitu RTH Publik dan RTH Privat, dengan demikian luas RTH Publik yang harus disediakan di D.I. Yogyakarta sebesar 637,16 km² dan dan luas RTH Privat yang harus disediakan sebesar $318,58 \mathrm{~km}^{2}$. Kebutuhan luas Ruang Terbuka Hijau Publik dan Privat berdasarkan luas wilayah keseluruhan D.I. Yogyakarta dapat dilihat pada Tabel 3 di bawah ini.

Tabel 3. Kebutuhan Luas Ruang Terbuka Hijau Publik dan Privat Berdasarkan Presentasi Wilayah D.I. Yogyakarta

\begin{tabular}{|c|c|c|}
\hline $\begin{array}{l}\text { RTH Menurut Fungsi } \\
\text { Penyediaannya }\end{array}$ & $\begin{array}{l}\text { Luas Wilayah D.I. } \\
\text { Yogyakarta }\left(\mathrm{km}^{2}\right)\end{array}$ & $\begin{array}{c}\text { Kebutuhan Luas RTH } \\
\left(\mathrm{km}^{2}\right)\end{array}$ \\
\hline RTH Publik & \multirow{2}{*}{3185,8} & 637,16 \\
\hline RTH Privat & & 318,58 \\
\hline \multicolumn{2}{|c|}{ Total Kebutuhan Luas RTH } & 955,74 \\
\hline
\end{tabular}

Sumber: Hasil analisis dan olah data, 2014

Kebutuhan RTH Publik dan Privat di D.I. Yogyakarta sangat dipengaruhi oleh luas wilayah masing-masing kabupaten/kota, hal ini dikarenakan kebutuhan RTH Publik dan Privat didasarkan pada luas wilayah. Jika dilihat pada Tabel 4, kebutuhan RTH paling tinggi terletak pada Kabupaten Gunungkiduldengan minimal lahan untuk RTH Publik yang harus disediakan sebesar 297,07 km² dan RTH Privat sebesar 148,5 $\mathrm{km}^{2}$. Kebutuhan RTH yang paling kecil/sedikit luasnya adalah Kota Yogyakarta dengan luas RTH Publik yang harus disediakan sebesar $6,5 \mathrm{~km}^{2}$ dan RTH Privat sebesar 3,3 $\mathrm{km}^{2}$. Kabupaten Bantul, Kulon Progo dan Sleman memiliki luas wilayah yang hampir sama, sehingga luas RTH yang dibutuhkan menurut luas wilayah hampir sama pada ketiga kabupaten tersebut. Kebutuhan luas RTH Publik berdasarkan luas wilayah di Kabupaten Bantul, Kulon Progo dan Sleman masing-masing sebesar 101,4 km², $117,3 \mathrm{~km}^{2}$, dan $114,96 \mathrm{~km}^{2}$. Sedangkang kebutuhan RTH Privat pada ketiga kabupaten tersebut masing-masing sebesar $50,7 \mathrm{~km}^{2}, 58,6 \mathrm{~km}^{2}$, dan $57,48 \mathrm{~km}^{2}$. Luas RTH minimum yang diperlukan dalam suatu wilayah tidak hanya ditentukan berdasarkan luas 
wilayah, akan tetapi secara komposit didasarkan oleh tiga komponen berikut ini, yaitu:

1. Kapasitas atau daya dukung alami wilayah,

2. Kebutuhan per kapita (kenyamanan, kesehatan, dan bentuk pelayanan lainnya), dan

3. Arah dan tujuan pembangunan kota.

Tabel berikut ini menyajikan hasil perhitungan luas dari masing-masing wilayah kajian dan besaran luas RTH yang harus disediakan mengacu pada peraturan perundang-undangan.

Tabel 4. Kebutuhan Luas Ruang Terbuka Hijau Publik dan Privat Menurut Kabupaten/Kota Berdasarkan Presentasi Wilayah D.I. Yogyakarta

\begin{tabular}{|c|c|c|}
\hline Kabupaten/Kota & Luas Wilayah $\left(\mathrm{km}^{2}\right)$ & $\begin{array}{c}\text { Kebutuhan Luas } \\
\text { RTH }\left(\mathrm{km}^{2}\right)\end{array}$ \\
\hline Kota Yogyakarta & 32,5 & \\
\hline RTH Publik & & 6,5 \\
\hline RTH Privat & & 3,3 \\
\hline Kabupaten Bantul & 506,86 & \\
\hline RTH Publik & & 101,4 \\
\hline RTH Privat & & 50,7 \\
\hline Kabupaten Gunungkidul & $1.485,36$ & \\
\hline RTH Publik & & 297,1 \\
\hline RTH Privat & & 148,5 \\
\hline Kabupaten Kulon Progo & 586,27 & \\
\hline RTH Publik & & 117,3 \\
\hline RTH Privat & & 58,6 \\
\hline Kabupaten Sleman & 574,82 & \\
\hline RTH Publik & & 114,96 \\
\hline RTH Privat & & 57,48 \\
\hline JUMLAH & $3.185,8$ & 955,7 \\
\hline
\end{tabular}

Sumber: Hasil analisis dan olah data, 2014

\section{Kebutuhan RTH Berdasarkan Jumlah Penduduk di DIY}

Pertumbuhan penduduk yang terus meningkat di D.I.Yogyakarta dapat dilihat dari jumlah penduduk yang dari tahun ke tahun selalu bertambah. Sensus terakhir yang dilakukan pada tahun 2013 menunjukkan bahwa penduduk D.I.Yogyakarta sejumlah 3.584.589 jiwa, dengankepadatan penduduk sebesar 1.125 jiwa per $\mathrm{km}^{2}$.Berdasarkan data sekunder yang diambil dari BPS Provinsi D.I. Yogyakarta dalam 
periode waktu tiga tahunan (dari tahun 2004-2012) diketahui bahwa hamplr setiap tiga tahunnya masing-masing kabupaten mengalami kenaikan jumlah penduduk sebesar $3-5 \%$. Hal tersebut menunjukkan pertumbuhan penduduk yang tinggi dapat berakibat kepada kepadatan penduduk yang semakin tinggi pula. Bertambahnya jumlah penduduk provinsi ini dari tahun ke tahun menyebabkan semakin sempitnya lahan khususnya lahan Ruang Terbuka Hijau (RTH). Oleh karena itu pemerintah D.I. Yogyakarta perlu mengalokasikan lahan khusus untuk RTH dan mempertahankan keberadaaannya dengan mempertimbangkan daya dukung alami wilayah dan penyediaan RTH berdasarkan kebutuhan per kapita.

Kebutuhan RTH perkapita dapat dihitung melalui standar yang telah ditetapkan (Peraturan Menteri PU No. 05/PRT/M/2008 tentang penyediaan dan pemanfaatan ruang terbuka hijau). Kebutuhan luas RTH berdasarkan jumlah penduduk, dilakukan dengan mengalikan antara jumlah penduduk yang dilayani dengan standar luas RTH per kapita. Berdasarkan hasil pengolahan dan analisis data kependudukan D.I. Yogyakarta pada tahun 2013, maka kebutuhan luas RTH menurut tipenya dapat dirinci seperti pada Tabel 5 di bawah ini.

Tabel 5. Kebutuhan RTH di D.I.Yogyakarta Berdasarkan Jumlah Penduduk Tahun 2013

\begin{tabular}{|c|c|c|c|c|c|c|c|c|}
\hline Kabupaten/Kota & $\begin{array}{l}\text { Luas } \\
\text { Wilayah } \\
\left(\mathrm{km}^{2}\right)\end{array}$ & $\begin{array}{l}\text { Jumlah } \\
\text { Penduduk }\end{array}$ & $\begin{array}{l}\text { Kebutuhan } \\
\text { Luas Taman } \\
\text { Kecamatan } \\
\left(\mathrm{m}^{2}\right)\end{array}$ & $\begin{array}{l}\text { Kebthn } \\
\text { Jumlah } \\
\text { Taman } \\
\text { Kec } \\
\end{array}$ & $\begin{array}{l}\text { Kebutuha } \\
\text { n Luas } \\
\text { Taman } \\
\text { Kota }\left(\mathrm{m}^{2}\right) \\
\end{array}$ & $\begin{array}{c}\text { Kebthn } \\
\text { Jumlah } \\
\text { Taman } \\
\text { Kota } \\
\end{array}$ & $\begin{array}{l}\text { Kebthn Luas } \\
\text { Hutan Kota } \\
\left(\mathrm{m}^{2}\right)\end{array}$ & $\begin{array}{l}\text { Kbthn } \\
\text { Jmlh } \\
\text { Hutan } \\
\text { Kota }\end{array}$ \\
\hline Kota Yogyakarta & 32,5 & 397.421 & $79.484,2$ & 3 & - & - & - & - \\
\hline Kabupaten Bantul & 506,85 & 956.517 & $191.303,4$ & 8 & $286.955,1$ & 2 & 3.826 .068 & 2 \\
\hline $\begin{array}{l}\text { Kabupaten } \\
\text { Gunungkidul }\end{array}$ & $1.485,36$ & 684.885 & $136.977,0$ & 6 & $205.465,5$ & 1 & 2.739 .540 & 1 \\
\hline $\begin{array}{l}\text { Kabupaten Kulon } \\
\text { Progo }\end{array}$ & 586,27 & 389.503 & $77.900,6$ & 3 & - & - & - & - \\
\hline $\begin{array}{l}\text { Kabupaten } \\
\text { Sleman }\end{array}$ & 574,82 & 1.156 .263 & $231.252,6$ & 10 & $346.878,9$ & 2 & 4.625 .052 & 2 \\
\hline JUMLAH & 3185,8 & 3584589 & $716.917,8$ & 30 & $1.075 .376,7$ & 7 & 14.338 .356 & 7 \\
\hline
\end{tabular}

Sumber: Hasil analisis dan olah data, 2014

Berdasarkan jumlah penduduk keseluruhan pada 5 kabupaten/kota di D.I. Yogyakarta pada tahun 2013 sebesar 45.138 jiwa, maka dapat dialokasikan tipe RTH berupa Taman RT, Taman RW, Taman Kelurahan, Taman Kecamatan, Taman Kota dan Hutan Kota. Meskipun demikian, dengan mempertimbangkan luas wilayah pada masing-masing kabupaten/kota secara keseluruhan secara makro, maka tipe RTH yang sesuai dan perlu dipertimbangkan dalam memenuhi kebutuhan RTH per kapita adalah Taman Kecamatan (pada level kecamatan), Taman Kota dan Hutan Kota (pada level kabupaten/kota).RTH berupa Taman Kecamatan di D.I. Yogyakarta yang 
dibutuhkan sejumlah 30 unit dengan luas yang berbeda-beda pada masing-masing kabupaten disesuaikan dengan jumlah penduduk yang dilayani. Sedangkan kebutuhan taman kota dan hutan kota sebagai penyangga sekaligus pemenuhan kebutuhan RTH D.I. Yogyakarta sejumlah 7 unit. Merujuk Tabel 5 di atas dapat dijelaskan kebutuhan RTH D.I. Yogyakarta berdasarkan jumlah penduduk sebagai berikut:

\section{Kota Yogyakarta}

Total kebutuhan RTH dengan tipe Taman Kecamatan seluas 79.484,2 $\mathrm{m}^{2}$ dengan jumlah yang dibutuhkan 3 unit. Diarahkan berlokasi dikelompokan dengan sekolah/pusat kecamatan.

> Berdasarkan jumlah penduduk di Kota Yogyakarta, kebutuhan RTH dengan tipe Taman Kota dan Hutan Kota belum diperlukan.

\section{Kabupaten Bantul}

> Total kebutuhan RTH dengan tipe Taman Kecamatan seluas 191.303,4 $\mathrm{m}^{2}$ dengan jumlah RTH Taman Kecamatan yang dibutuhkan 8 unit. Diarahkan berlokasi dikelompokan dengan sekolah/pusat kecamatan.

> Total kebutuhan RTH dengan tipe Taman Kota seluas 286.955,1 $\mathrm{m}^{2}$ dengan jumlah RTH Taman Kota yang dibutuhkan 2 unit. Diarahkan berlokasi di pusat wilayah/kota.

> Total kebutuhan RTH dengan tipe Hutan Kota seluas $3.826 .068 \mathrm{~m}^{2}$ dengan jumlah RTH Hutan Kota yang dibutuhkan 2 unit. Diarahkan berlokasi di dalam/kawasan pinggiran.

Kabupaten Gunungkidul

$>$ Total kebutuhan RTH dengan tipe Taman Kecamatan seluas $136.977 \mathrm{~m}^{2}$ dengan jumlah RTH Taman Kecamatan yang dibutuhkan 6 unit. Diarahkan berlokasi dikelompokan dengan sekolah/pusat kecamatan.

Total kebutuhan RTH dengan tipe Taman Kota seluas 205.465,5 $\mathrm{m}^{2}$ dengan jumlah RTH Taman Kota yang dibutuhkan 1 unit. Diarahkan berlokasi di pusat wilayah/kota.

Total kebutuhan RTH dengan tipe Hutan Kota seluas $2.739 .540 \mathrm{~m}^{2}$ dengan jumlah RTH Hutan Kota yang dibutuhkan 2 unit. Diarahkan berlokasi di dalam/kawasan pinggiran.

* Kabupaten Kulon Progo

> Total kebutuhan RTH dengan tipe Taman Kecamatan seluas 77.900,6 $\mathrm{m}^{2}$ dengan jumlah yang dibutuhkan 3 unit. Diarahkan berlokasi dikelompokan dengan sekolah/pusat kecamatan. 
Berdasarkan jumlah penduduk di Kabupaten Gunungkidul, kebutuhan RTH dengan tipe Taman Kota dan Hutan Kota belum diperlukan.

* Kabupaten Sleman

> Total kebutuhan RTH dengan tipe Taman Kecamatan seluas 231.252,6 $\mathrm{m}^{2}$ dengan jumlah RTH Taman Kecamatan yang dibutuhkan 10 unit. Diarahkan berlokasi dikelompokan dengan sekolah/pusat kecamatan.

$>$ Total kebutuhan RTH dengan tipe Taman Kota seluas $346.878,9 \mathrm{~m}^{2}$ dengan jumlah RTH Taman Kota yang dibutuhkan 2 unit. Diarahkan berlokasi di pusat wilayah/kota.

$>$ Total kebutuhan RTH dengan tipe Hutan Kota seluas $4.625 .052 \mathrm{~m}^{2}$ dengan jumlah RTH Hutan Kota yang dibutuhkan 2 unit. Diarahkan berlokasi di dalam/kawasan pinggiran.

Peningkatan jumlah penduduk D.I. Yogyakarta dimasa yang akan datang tersebut memperlihatkan bahwa perkembangan wilayah akan semakin padat serta tekanan yang tinggi terhadap pemanfaatan ruang.

\section{SIMPULAN}

1. Tren perkembangan penduduk di D.I. Yogyakarata dari tahun 2004-2022 cenderung mengalami kenaikan secara stabil, fluktuasi penambahan maupun penurunan jumlah penduduk terjadi pada tahun 2007-2010.

2. Tren perkembangan penduduk D.I. Yogyakarata dari tahun 2004-2022 yang menunjukkan peningkatan jumlah penduduk cukup signifikan adalah Kabupaten Sleman dan Kabupaten Bantul, dengan jumlah penduduk terbesar tetap berada di Kabupaten Sleman.

3. Kebutuhan RTH berdasarkan luas wilayah paling besar berada pada di Kabupaten Sleman, sedangkan kebutuhan RTH berdasarkan jumlah penduduk yang paling besar berada di Kabupaten Gunungkidul.

4. Kebutuhan luas RTH Publik dan Privat berdasarkan luas wilayah D.I. Yogyakarata sebesar $637,16 \mathrm{~km}^{2}$ dan $318,58 \mathrm{~km}^{2}$, sehingga total kebutuhan RTH $30 \%$ dari luas wilayah sebesar $955,47 \mathrm{~km}^{2}$.

5. Tipe RTH yang sesuaidanperludipertimbangkandalammemenuhikebutuhan RTH per kapitadi D.I. Yogyakartaadalah Taman Kecamatan (pada level kecamatan), Taman Kota danHutan Kota (pada level kabupaten/kota).

6. RTH yang dibutuhkan di D.I. Yogyakarta berupa Taman Kecamatan (30 unit), RTH berupa taman kota dan hutan kota (7 unit) dengan luas yang bervariasi pada masing-masing kabupaten sesuai dengan jumlah penduduk yang dilayani. 
7. Kebutuhan RTH berdasarkan jumlah pendudukdi D.I. Yogyakarta berbanding lurus dengan perkembangan jumlah penduduk, semakin banyak jumlah penduduk maka semakin besar pula kebutuhan RTH per kapita.

\section{DAFTAR PUSTAKA}

Pertumbuhan Penduduk. http://wikipedia.org. Diunduh pada 14 April 2014.

Bintarto, R.. 1987. Pengantar Geografi Kota. Spring, Yogyakarta.

BPS Indonesia. 2014. Artikel tentang Pertumbuhan Penduduk.Data Statistik Indonesia, Jakarta.

Deputi MENLH Bidang Tata Lingkungan. 2007. Buku Pegangan Kajian Lingkungan Hidup Strategis. Kementrian Lingkungan Hidup, Jakarta.

Dyah. 2012. Konsep Kependudukan di Indonesia. http://jurnalbidandiah.blogspot.com. Diunduh pada 14 April 2014.

Kementrian Pekerjaan Umum. 2011. Program Pengembangan Kota Hijau (P2KH). Jakarta, Kementrian Pekerjaan Umum.

Mantra, Ida Bagoes. 2007. Demografi Umum. Edisi Kedua. Yogyakarta, Pustaka Pelajar.

McGee, T. G. 1977. Rural-Urban Mobility in South and Southeast Asia. Different Formula...Different Answer?. Janet Abu Lughod, Richard Hay, Jr. (eds). Metheun, New York.

Ritohardoyo, Su. 2013. Perencanaan Penggunaan Lahan. Penerbit Ombak, Yogyakarta.

Samuelson, P.A. dan Nordhaus W.D. 1995. Economic Fifteenth Edition.: McGraw-Hill, Inc, New York.

Satyohutomo, M. 2009. Manajemen Kota dan Wilayah, Realita dan Tantangan. PT. Bumi Aksara, Jakarta.

Soemarwoto, Otto. 1998. Analisis Dampak Lingkungan. Yogyakarta: Gadjah Mada University Press.

Yasin, Moh. 1983. Arti dan Tujuan Demografi, Dasar-Dasar Demografi. Lembaga Demografi FEUI, Jakarta.

Yunus, Hadi Sabari. 2002. Struktur Tata Ruang Kota. Pustaka Pelajar, Yogyakarta.

\section{Sumber dari Peraturan Perundangan}

Undang-Undang Republik Indonesia Nomor 10 tahun 1992 tentang Perkembangan Kependudukan dan Pembangunan Keluarga Sejahtera.

Undang-Undang Republik Indonesia Nomor 12 Tahun 2006 tentang Kewarganegaraan Republik Indonesia.

Peraturan Menteri Dalam Negeri Nomor 1 Tahun 2007 tentang Penataan Ruang Terbuka Hijau Kawasan Perkotaan.

Peratutan Menteri Pekerjaan Umum Nomor 05/PRT/M/2008 tentang Pedoman Penyediaan dan Pemanfaatan Ruang Terbuka Hijau di Kawasan Perkotaan.

Peraturan Daerah Provinsi Daerah Istimewa Yogyakarta No. 2 Tahun 2010 mengenai Rencana Tata Ruang Wilayah (RTRW) D.I. Yogyakarta. 